Vol 04 No 2 (2020)
$\begin{gathered}\text { Inventa: Jurnal Pendidikan Guru Sekolah Dasar } \\ \text { http://jurnal.unipasby.ac.id/index.php/jurnal_inventa }\end{gathered}$

\title{
Pengaruh Pembelajaran Online Terhadap Kemandirian Belajar Siswa Kelas II SD Muhammadiyah 17 Surabaya di Tengah Pandemi Covid-19
}

\author{
Aden Fani Rahmasari' ${ }^{1)}$, Fajar Setiawan ${ }^{2)}$, Meirza Nanda Faradita ${ }^{3)}$ \\ Pendidikan Guru Sekolah Dasar \\ Universitas Muhammadiyah Surabaya
}

Corresponding author email: aden.fani.rahmasari-2016@fkip.um-surabaya.ac.id

\begin{tabular}{ll}
\hline & Abstrak \\
\hline Kata Kunci: Pandemi & Pandemi COVID-19 adalah krisis kesehatan yang pertama kali ada di \\
COVID-19, Pengaruh & seluruh dunia terutama menyerang imunitas setiap orang sehingga \\
Pembelajaran Online & menjadi momok bagi setiap masyarakat yang sebagian besar aktivitasnya \\
& dilakukan di rumah akibat adanya pandemi tersebut. Wabah COVID-19 \\
& ini telah melanda 215 negara di dunia dan telah memberikan tantangan \\
& tersendiri bagi lembaga pendidikan, baik dari Sekolah Dasar, Sekolah \\
& Menengah Pertama, Sekolah Menengah Atas maupun di Perguruan \\
& Tinggi. Penyebab dari wabah COVID-19, membuat semua kegiatan dari \\
& mulai sekolah, pekerjaan harus di tutup sementara waktu guna memutus \\
& rantai penyebaran COVID-19. COVID-19 merupakan sebuah virus yang \\
& menyerang pernafasan manusia (Kementerian Kesehatan, 2020 ). Tujuan \\
& dari penelitian ini untuk mendapatkan informasi terkait pandemi COVID- \\
& 19 terhadap pengaruh belajar siswa di SD Muhammadiyah 17 Surabaya. \\
& Masih ada keuntungan dari melakukan pembelajaran online yang saat ini \\
& dilakukan seperti meningkatkan daya ingat siswa, memberikan wawasan \\
& yang luas dengan pengalaman mereka melalui teks, video dan audio. \\
Bukan hanya itu saja orang tua lebih sering memantau anak-anaknya dari \\
rumah sehingga orang tua tidak khawatir dengan anaknya yang \\
ketingggalan pelajaran.
\end{tabular}

\section{Abstract}

Keywords: Pandemic COVID-19, The impact of online learning
The COVID-19 pandemic is the first health crisis in the entire world, especially attacking the immunity of everyone so that it becomes a scourge for every community whose activities are mostly carried out at home due to the pandemic. This COVID-19 outbreak has hit 215 countries in the world and has given its own challenges for educational institutions, both from elementary schools, high schools and in Universities. The cause of the COVID-19 outbreak, making all activities starting from school, work had to be temporarily closed to break the chain of COVID-19 distribution. COVID-19 is a virus that attacks human respiration (Ministry of Health, 2020). The purpose of this study was to obtain information related to the COVID-19 pandemic on the effect of student learning at SD Muhammadiyah 17 Surabaya. There are doing online learning that are currently being don such as improving student memory, providing broad insight into their experiences through text, video and audio. Not only that, parents are more often monitoring their children being left behind. 


\section{Pendahuluan}

Pandemi COVID-19 adalah krisis kesehatan yang pertama kali ada di seluruh dunia terutama menyerang imunitas setiap orang sehingga menjadi momok bagi setiap masyarakat yang sebagian besar aktivitasnya dilakukan di rumah akibat adanya pandemi tersebut. Wabah COVID-19 ini telah melanda 215 negara di dunia dan telah memberikan tantangan tersendiri bagi lembaga pendidikan, baik dari Sekolah Dasar, Sekolah Menengah Pertama, Sekolah Menengah Atas maupun di Perguruan Tinggi. Tidak dapat dipungkiri bahwasannya pandemi covid-19 telah merubah tatanan gaya hidup sebagaian besar penduduk di dunia, termasuk dunia pendidikan. Di era Revolusi Industri 4.0 yang marak digalakkan sejak tahun 2019 di Indonesia sekarang benar-benar terasa mengalami akselerasi. Penyampaian pendidikan, dalam kegiatan formal maupun informal dialihkan pada metode online ataupun dalam jaringan secara radikal dan masif. Penyebab dari wabah COVID-19, membuat semua kegiatan dari mulai sekolah, pekerjaan harus di tutup sementara waktu guna memutus rantai penyebaran COVID-19. COVID19 merupakan sebuah virus yang menyerang pernafasan manusia (Kementerian Kesehatan, 2020 ). Virus ini masih berhubungan dengan penyebab SARS dan MERS yang sempat mucul pada tahun 2019 yang lalu. Diketahui ketiga virus ini disebarkan oleh hewan dan mampu menjangkit dari satu spesies lainnya termasuk manusia. Cara penyebarannya disebut transmisi atau kata lain dari zoonosis, beberapa hal yang harus dilakukan di dalam pencegahan virus corona ini menurut (Kementerian Dalam Negeri, 2020). Yaitu dengan melakukan kebersihan tangan menggunakan hand sanitizer jika tangan tidak terlihat kotor, menghindari kerumunan, menghindari menyentuh mata, hidung serta mulut sehabis melakukan aktivitas. (Pratiwi, 2020) Pihak pemerintah telah melarang untuk berkerumun, pembatasan sosial (social distancing) dan menjaga jarak fisik (phsyical distancing) sehingga pemerintah menganjurkan semua kegiatan apapun untuk sementara waktu hanya dikerjakan dirumah terutama dunia pendidikan. Di sekolah dasar maupun perguruan tinggi saat ini (Ali Sadekin, 2020) melakukan pembelajaran online secara mandiri di rumah. Pengaruh pandemi ini sangat berpengaruh terutama kegiatan sekolah, maka dari itu kebijakan dari pihak pemerintah untuk melakukan pembelajaran secara online terhadap siswa. Pembelajaran secara online tersebut, menjadikan siswa cenderung 
bosan ketika diberikan tugas oleh guru.

Penyebaran virus wabah corona ini pada mulanya berdampak pada perekonomian yang mulia menurun, tetapi kini dampaknya juga dirasakan di dunia pendidikan. kebijakan yang dilakukan pemerintah luar negeri maupun di Indonesia dengan meliburkan sekolahsekolah dan menggantikannya dengan belajar di rumah dengan melalui sistem online. Kebijakan pemerintah pun juga berlaku pada pendidikan diperguruan tinggi, mahasiswanya melakukan pembelajaran secara sistem online. Selama pandemi ini berlangsung, pembelajaran kali ini secara daring yang sudah dilakukan hampir seluruh dunia (Goldschmidt, 2020) sehingga pembelajaran daring ini, semua elemenelemen pendidikan dituntut untuk bertatap muka dan mampu memfasilitasi pembelajaran agar tetap aktif meskipun tanpa tatap muka langsung dengan siswa. (Setyorini, 2020) Sebanyak 13 negara termasuk di China, Italia, dan juga di Jepang telah menutup lembaga sekolah upaya untuk menghentikan penyebaran virus corona. Hal ini mempengaruhi hampir 290 juta siswa kata UNESCO. Pejabat kesehatan saat ini tidak merekomendasikan penutupan sekolah jika tidak ada kasus corona virus lokal dan sebaliknya, mereka lebih menekankan perilaku sehat seperti cuci tangan dengan air sabun panas, tinggal di rumah saat sakit, memakai masker jika sedang batuk atau sakit, dan terpenting jaga jarak agar tidak terjangkit virus corona.

Sebagian besar siswa-siswa berasal dari China yang termasuk wilayah wabah corona berasal. Lebih dari 233 juta siswa yang mengalami tidak sekolah karena adanya virus corona tersebut. Korban akibat pandemi COVID-19 ini, tidak hanya berpengaruh di sekolah dasar/madrasah, sekolah menengah pertama, sekolah menengah atas dan perguruan tinggi akan dipaksa untuk melakukan semua pembelajaran online secara mandiri di rumah melainkan semua aktivitas guru juga sangat berpengaruh dan berbeda dari yang biasanya. Di samping itu juga selain dunia pendidikan yang banyak kendala, pekerjaan lainnya juga mendapatkan pengaruh yang sangat besar. Banyak kendala yang terjadi adanya pandemi ini seperti guru di SD Muhammadiyah 17 Surabaya sering mengontrol siswanya dari jarak jauh seperti meminta orang tua siswa untuk mendampingi anaknya dalam mengerjakan tugas kemudian memberikan bukti foto untuk dikirimkan pada gurunya. Badan UNESCO mengatakan bahwa akan menutup program dan menjalankan pembelajaran jarak jauh berskala besar untuk 
menjangkau semua siswa dengan jarak jauh. Dampak dari pandemi tersebut, mulai merambah dunia pendidikan, pemerintahan pusat, dan daerah-daerah memberikan kebijakan dalam meliburkan seluruh lembaga pendidikan yang ada di Indonesia. Pemerintah mengharapkan dengan kebijakan tersebut, seluruh lembaga pendidikan masih dapat memantau siswa-siswanya melalui jarak jauh seperti pembelajaran secara mandiri dengan melakukan pembelajaran online sehingga siswa tidak tertinggal pembelajarannya. Kebijakan tersebut sangat membantu untuk memutuskan rantai penyebaran virus corona ini di Indonesia agar, virus wabah corona cepat berakhir dan semua aktivitas masyarakat maupun siswa kembali normal seperti semua. Teknologi informasi dan komunikasi (TIK) menwarkan berbagai kemungkinan untuk meningkatkan kualitas pembelajaran. TIK juga dapat dimanfaatkan untuk peningkatan dan pengembangan kemampuan profesional dosen ataupun guru sebagai sumber belajar dalam pembelajaran, sebagai alat bantu interaksi pembelajaran maupun wadah pembelajaran (Depdiknas, 2004) dalam artikel Diana Novita, dkk hal: 1. Bukan hanya dunia pendidikan yang merasakan perbedaan karena pandemi ini melainkan tempat-tempat ibadah juga mulai melakukan kebijkan yang sama untuk memutuskan rantai penyebaran virus ini dan meminta seluruh masyarakat tidak melakukan ibadah di tempat biasanya dilakukan melainkan beribadah di rumah. Begitu besar pengaruh pandemi COVID- 19 saat ini terutama dunia pendidikan yang sangat berbeda dilakukan. Begitulah dampak dari pengaruh pandemi COVID-19 yang terjadi di seluruh dunia yang sangat menghambat segala aktivitas masyarakat dan juga berdampak pada siswa yang melakukan aktivitas sekolah dengan di rumah. Guru melakukan pekerjaannya dengan melalui online seperti memberikan tugas setiap hari, membuat laporan untuk dikirimkan kepada Dinas Pendidikan juga melalui sistem online. Jelas sangat berbeda dari biasanya begitu juga yang dirasakan siswa yang biasanya berkegiatan di sekolah dan selalu bertemu dengan teman-temannya, sekarang harus benar-benar belajar di rumah secara mandiri sehingga membuat anak cenderung bosan dan ingin kembali normal seperti dulu yang dimana tidak ada virus corona. Belum cukup sampai itu saja sekolah dan kampus ikut sistem didaringkan, lengkap sudah virus corona ini membuat siswa yang akan melaksanakan Ujian Nasional (UN) tahun ini pihak pemerintahan juga menetapkan tidak akan dilaksanakan dan pengumuman kelulusan melalui sistem 
online. Mulai dari tingkat Sekolah Dasar sampai tingkat Sekolah Menengah Atas untuk tahun 2020. Bukan hanya merambah dunia pendidikan saja melainkan dunia kesehatan saat ini tidak merekomendasikan penutupan sekolah jika tidak ada virus wabah corona. Begitupun sebaliknya mereka menekankan gaya hidup sehat seperti mencuci tangan terlebih dahulu sebelum melakukan aktivitas atau sesudah beraktivitas diluar, makan-makanan yang sehat dan bergizi dan mengkonsumsi vitamin agar menghindari virus yang saat ini sedang marak di seluruh dunia. Tujuan dari penelitian ini untuk mendapatkan informasi terkait pandemi COVID-19 terhadap pengaruh belajar siswa di SD Muhammadiyah 17 Surabaya. Masih ada keuntungan dari melakukan pembelajaran online yang saat ini dilakukan seperti meningkatkan daya ingat siswa, memberikan wawasan yang luas dengan pengalaman mereka melalui teks, video dan audio. Bukan hanya itu saja orang tua lebih sering memantau anak-anaknya dari rumah sehingga orang tua tidak khawatir dengan anaknya yang ketingggalan pelajaran.

\footnotetext{
Menteri Nadiem Makarim menerbitkan Surat Edaran Nomor 3 Tahun 2020 pada Satuan Pendidikan dan Nomor 36962/MPK.A/HK/2020 tentang
}

Pelaksanaan Pendidikan dalam masa darurat Coronavirus Disease (COVID19) maka dari itu kegiatan belajar dilakukan secara daring atau (online). Hal ini untuk mencagah atau memutuskan rantai penyebaran COVID19. (Menteri Pendidikan, 2020: 57). Penelitian yang saya lakukan relevan dengan penelitian dari Sukma Erni, Rian Vebrianto, Cut Raudhatul Miski, Zubaidah Amir MZ, Martius, Musa Thahir (2020) dalam jurnal artikel yang berjudul "Refleksi Proses Pembelajaran Guru MTs dimasa Pandemi COVID-19 di Pekanbaru: Dampak dan Solusi”. Menyatakan kesimpulan bahwa dengan adanya masa pandemi covid-19 ini, sistem pembelajarannya menggunakan via grup WA yang dilakukan guru dalam memberikan tugas-tugas sebagai pengganti mengajar selama pandemi. Dan dari penelitian tersebut, pihak sekolah sudah berusaha memberikan upaya dalam bentuk pembelajaran sehingga siswa tetap melaksanakan sekolah berdasarkan anjuran pemerintah.Sayajugamengambilpenelitia n relevan dari Eva Luttfi Fakhry Ahsani yang berjudul "Strategi Orang Tua dalam Mengejar dan Mendidik Anak dalam Pembelajaran At The Home Masa Pandemi COVID-19". Dalam penelitian ini, sistem yang dilakukan guru dalam memberikan pembelajaran melalui 
aplikasi WhatsApp, edmodo, schoology, atau yang lainnya sehingga pembelajaran yang dilakukan orang tua maupun guru tetap berjalan sesuai dengan anjuran pemerintahan.

\section{Metode Penelitian}

$\begin{array}{ccc} & \text { Berhubung adanya wabah } \\ \text { COVID 19, maka penelitian ini }\end{array}$ menggunakan metode studi kasus melalui Google Form yaitu mengirimkan pertanyaan yang berkaitan dengan permasalahan saat ini. Kemudian saya mengirimkan linknya melalui wali kelas untuk disebarkan ke wali murid agar mengetahui bagaimana respon dari masing-masing mengenai pembelajaran daring yang dilakukan ditengah pandemic COVID 19. Penelitian yang saya lakukan saat ini untuk mendapatkan informasi atas kendala pembelajaran saat ini. (Agus Purwanto 2020: 1). Selain melalui Google Form penelitian ini juga melakukan wawancara dengan wali kelas II di SD Muhammadiyah 17 Surabaya dengan cara via chatting untuk mendapatkan informasi selama kegiatan pembelajaran daring. Menurut Guetterman (2015), ukuran sampel bukan masalah opini representatif dan pandangan, tetapi lebih merupakan masalah-masalah informasi. Penelitian ini hanya bisa dilakukan secara online seperti mengirimkan link google form secara tertulis untuk mendapatkan beberapa responden dari wali murid kelas II. Alasan utama peneliti melakukan hal tersebut adalah untuk menghindari jarak yang terlalu berdekatan sehingga peneliti hanya bisa mengambil data dengan cara mengirimkan beberapa pertanyaan yang terkait dengan pembelajaran daring ditengah pandemic COVID-19. Maka dari itu, peneliti melakukan wawancara dengan wali kelas II SD Muhammadiyah 17 Surabaya via chatting whatsapp dan tidak bertatap muka langsung. Untuk menggali informasi dari responden, peneliti memberikan 10 pertanyaan yang berkaitan masalah yang ada saat ini :

1. Bagaimanakah respon siswa dalam melaksanakan pembelajaran daring/online selama pandemic COVID-19 ini ?

2. Jelaskan manfaat dari pembelajaran daring/online dalam masa pandemic COVID-19!

3. Bagaimanakah respon orang tua dalam mendampingi anakanaknya selama pembelajaran online ?

4. Apakah ada kendala saat siswa menggunakan pembelajaran daring ? Jelaskan !

5. Apakah siswa senang dalam belajar melalui online? 
6. Pembelajaran daring/online seperti apa yang lebih dilakukan guru terhadap memberikan pelajaran?

7. Setujukah jika pembelajaran daring/online diperlukan selama pandemic COVID-19?

8. Bagaimanakah saran orang tua untuk guru dalam pembelajaran daring ?

9. Apa tanggapan orang tua mengenai pandemic COVID-19 saat ini ?

10. Apa upaya orang tua dalam mendampingi anak selama pembelajaran di rumah?

\section{Hasil Penelitian}

Tujuan dari penelitian ini yaitu untuk mendapatka informasi-informasi mengenai dampak dari pembelajaran yang dilakukan secara daring ditengah pandemi COVID-19. Adapun respon dari walimurid kelas II SD Muhammadiyah 17 Surabaya mengenai pertanyaan yang saya ajukan melalui google form. Berikut hasil pernyataan dari responden :

Responden pertanyaan pertama sebanyak 10 orang memilih Lebih senang karena belajarnya di rumah dan bisa didampingi oleh orang tua. Dan 10 orangnya lagi memilih Merasa bosan karena pembelajarannya melalui online.
Pertanyaan kedua responden sebanyak 21 orang memilih Lebih praktis dalam menghindari virus corona yang saat ini terjadi. Dan 1 orang memilih Bisa dilakukan di mana saja.

Pertanyaan ketiga responden sebanyak 12 orang memilih Lebih bisa memantau perkembangan anaknya dalam pembelajaran, 6 orang memilih Terhalang kelemahan sinyal pada saat mendampingi anak dalam pembelajaran daring, dan 4 orang memilih Lebih dekat pada saat mengajari anak belajar.

Pertanyaan keempat responden sebanyak 12 orang yang memilih Ada, sinyal terkadang jelek dan tidak punya uang untuk membeli kuota ditengah ekonomi yang turun karena pandemi corona saat ini, 9 orang lainnya memilih Ada, contohnya seperti ada tugas atau UTS yang diberikan deadline oleh gurunya, dan 1 orang memilih Ada, misalnya jaringan dalam berkomunikasi juga.

Pertanyaan kelima responden sebanyak 17 orang memilih Lebih senang belajar secara langsung, 3 orang memilih $Y a$, dan 2 orang memilih Tidak.

Pertanyaan keenam responden memilih Memberikan tugas-tugas dengan menggunakan google form sebanyak 22 orang. 
Pertanyaan ketujuh responden memilih

Setuju, karena orangtua lebih mudah mendampingi anak dalam belajar selama dirumah sebanyak 14 orang, 7 orang lain memilih Anak lebih senang belajar disekolah, dan 2 orang memilih Tidak, karena anak lebih mudah bosan jika belajarnya melalui online.

Pertanyaan kedelapan responden 15 orang yang memilih Memberikan materi yang lebih menarik agar tidak merasa bosan saat belajar dirumah dan 7 orang memilih, terlalu sering memberikan tugas pada anak agar tidak banyak beban.

Pertanyaan kesembilan responden sebanyak 16 orang memilih Seтиa aktivitas dilakukan dirumah dan membuat anak tidak bisa bebas dalam bermain, sering memberikan arahan yang baik untuk menjaga kesehatan, 6 orang lain memilih Membatasi anak dalam bermain agar tidak terkena virus yang terjadi saat ini.

Dan pertanyaan terakhir responden sebanyak 12 orang memilih Mengajarinya jika ada tugas yang sulit, dan 10 orang lainnya memilih Selalu mengingatkan apakah ada tugas dari guru.

\section{Pembahasan}

Beberapa responden yang telah memberikan pernyataan dan pendapat akan dibahas sebagai berikut ini :

\section{Dampak Terhadap Siswa}

Dampak yang dirasakan oleh siswa selama pembelajaran di rumah memaksa siswa untuk belajar jarak jauh dan cenderung bosan karena siswa terbiasa belajar di sekolah dengan bertemu teman-temannya. Sedangkan untuk saat ini, siswa diharuskan untuk belajar di rumah dengan berjaga jarak dalam waktu yang belum bisa dipastikan. Untuk kendalanya adalah mungkin masih ada beberapa siswa yang bisa melakukan pembelajaran daring atau kemungkinan orang tuanya cenderung sibuk sehingga waktu untuk mendampingi anaknya sedikit susah selain itu juga adapun orang tua dari siswa memiliki handphone atau laptop, kendalanya pada di internet terkadang sinyal dari internet jelek sehingga pembelajarannya terganggu. Perubahan yang terjadi saat ini membuat siswa cenderung bingung sehingga daya serap belajar mereka juga berpengaruh dan mereka yang biasanya belajar secara tatap muka harus terpaksa diliburkan dengan kegiatan belajar di rumah secara online. Itulah dampak yang terjadi saat ini dirasakan oleh siswa. Bukan hanya itu saja yang terjadi, untuk siswa baru juga 
merasakan dampak yang luar biasa di tahun ini dengan melakukan perkenalan menggunakan aplikasi zoom metting. Temuan menunjukkan siswa online lebih cenderung memiliki gaya belajar visual dan baca tulis yang lebih kuat dan bagus.

\section{Dampak Terhadap Guru}

\section{Dampak yang dirasakan guru} adalah tidak semua guru mahir dalam teknologi sehingga kesulitan dalam menyampaikan pembelajaran yang ingin disampaikan pada siswanya. Terutama guru yang sudah berumur pasti kerepotan dalam memberikan materi sehingga meminta pada rekan kerjanya dalam membantu pembelajaran daring. Dan kompetensi guru dalam menggunakan teknologi akan mempengaruhi kualitas program belajar mengajar oleh karena itu, sebelum diadakannya program belajar online semua guru wajib untuk diberikan pelatihan terlebih dahulu sebelum melakukan pembelajaran daring. Bukan hanya itu saja dampak yang dialami para guru ada pula beberapa guru yang kesulitan dalam mengoperasikan laptop pada saat di rumah sehingga menghambat proses pembelajaran. Fasilitas ini snagatlah penting bagi guru dalam hal memberikan materi untuk siswanya seperti laptop, handphone untuk memudahkan guru dalam mengajar. Kendala yang berikutnya adalah guru belum terbiasa dalam mengajar secara jarak jauh karena selama ini sistem pembelajarannya dilakukan di sekolah dan bertatap muka langsung dengan siswa-siswanya. Dengan adanya metode pembelajaran jarak jauh yang membuat guru perlu waktu untuk beradaptasi menghadapi perubahan baru yang secara tidak langsung akan mempengaruhi kualitas hasil belajar siswa. Berikutnya yaitu dampak yang dialami guru adalah lembaga sekolah diliburkan sampai waktu yang tidak bisa dipastikan membuat semua guru jenuh, guru terbiasa berada di sekolah untuk berinteraksi dengan rekan kerjanya. Kompetensi guru dalam memanfaatkan teknologi dan menguasainya untuk pembelajaran di tuntut dalam meningkatkan dengan cepat untuk merespon online Home Learning dan komunikasi antara guru dan orang tua siswa harus terjalin lancar. Artinya, harus ada tambahan pengeluaran biaya yang harus dibayar oleh guru baik berupa material maupun non material. Contohnya pulsa telfon, pulsa untuk akses internet, dan terutama waktu. Menurut Chakraborty, 2014 (dalam jurnal Agus Purwanto 2020: 8) mengungkapkan beberapa faktor yang dapat menciptakan pengalaman belajar yang menarik dalam pembelajaran online. Faktor utama adalah menciptakan 
dan memelihara lingkungan belajar yang positif, membangun komunitas belajar, memberikan umpan balik yang konsisten pada siswa, dan menggunakan teknologi yang tepat. Guru lebih berwawasan luas dalam menentukan strategi dalam mengajar agar siswa yang akan menerima materi pembelajaran tidak merasa bosan dan cenderung pasif ketika pembelajaran online dilakukan.

\section{Dampak Terhadap Orang Tua}

Dampak dari pembelajaran online ini juga berpengaruh pada orang tua karena orang tua harus selalu menemani anaknya dalam pembelajaran online. Orang tua harus bisa sabar dalam menghadapi situasi dan kondisi pada saat ini dengan adanya pembelajaran online, disamping itu juga orang tua menjadi peran penting untuk anak agar merasakan senang ketika belajar di rumah setidaknya anak tidak merasa bosan ketika sedang belajar di rumah selama pandemi COVID-19 ini. Kendala yang terjadi pada orang tua ketika sedang ada pekerjaan di rumah sehingga anak tidak ada yang mendampingi selama pembelajaran online. Bukan hanya itu saja keluhan yang dirasakan orang tua ada pada kuota internet yang terkadang tidak stabil sehingga pembelajaran online terhambat. Itulah dampak yang dirasakan baik siswa, para guru, dan juga orang tua terkait adanya pembelajaran yang dilakukan secara online.

\section{Kesimpulan}

Dari beberapa dampak yang dirasakan siswa yaitu pada proses belajar yang terlalu dipaksakan menerima pembejaran online secara jarak jauh dengan menggunakan aplikasi zoom metting atau guru mengirimkan materi melalui link google form untuk dikerjakan oleh siswa. Fasilitas teknologi seperti handphone dan laptop sangat penting untuk proses belajar siswa selam di rumah namun, masih ada beberapa siswa yang tidak memiliki laptop sehingga mereka kebingungan dalam belajar online. Dampak ini berpengaruh sekali untuk siswa selama pandemi C0VID-19 mereka terpaksa belajar di rumah dan tidak bertemu temantemannya. Para guru lebih cenderung meminta bantuan pada rekan kerjanya yang lebih mudah dalam membantu dalam memberikan materi agar pembelajarannya berjalan lancar namun masih saja kendala yang terjadi yaitu dengan koneksi internet yang terkadang sering tidak stabil yang membuat guru tersebut susah untuk mengajar. 


\section{Daftar Pustaka}

Dari Jurnal

Agus Purwanto*, R. P. (2020). Studi Eksploratif Dampak Pandemi COVID-19 Terhadap Proses Pembelajaran Online di Sekolah Dasar. Journal of Education, Psychology and Counseling.

Ahsani, E. L. (2020). Strategi Orang Tua dalam Mengajar dan Mendidik Anak dalam Pembelajaran At The Home Masa Pandemi Covid-19. JurnalAl_Athfal.

Ali Sadekin, A. H. (2020). Pembelajaran Daring di Tengah Wabah Covid-19. Jurnal Ilmiah Pendidikan Biologi, 110.

Dewi, W. A. (2020). Dampak Covid-19 terhadap Implementasi Pembelajaran Daring di Sekolah Dasar. Jurnal Ilmu Pendidikan, 57.

Diana Novita, A. R. (2020). Plus Minus Penggunaan Aplikasi-Aplikasi Pembelajaran Daring Selama Pandemi COVID-19. Jurnal Posmedia.com.

Handarini, O. I. (2020). Pembelajaran Daring Sebagai Upaya Study From Home (SFH) Selama Pandemi Covid-19. Jurnal Pendidikan Administrasi Perkantoran (JPAP).

Pratiwi, E. W. (2020). DAMPAK COVID-19 TERHADAP KEGIATAN PEMBELAJARAN ONLINE DI SEBUAH PERGURUAN TINGGI KRISTEN DI INDONESIA. Perspektif Ilmu Pendidikan, 2.
Setyorini, I. (2020). PANDEMI COVID-19

ONLINE LEARNING : APAKAH BERPENGARUH TERHADAP PROSES

PEMBELAJARAN

PADA

KURIKULUM 13 ? Journal of Industrial Engineering \& Management Research (JIEMAR), 96.

Sukma Erni, R. V. (2020). Refleksi Proses Pembelajaran Guru MTs dimasa Pandemi COVID-19 di Pekanbaru: Dampak dan Solusi. Journal of Education and Learning.

Yuanita Rachmawati, M. M. (2020). Studi Eksplorasi Pembelajaran Pendidikan IPA Saat Masa Pandemi COVID-19 di UIN Sunan Ampel Surabaya. Indonesian Journal of Science Learning. 